Article

\title{
Smallholder-Based Oil Palm and Rubber Production in the Forest Region of Guinea: An Exploratory Analysis of Household Food Security Outcomes
}

\author{
Boubacar Siddighi Balde ${ }^{1, *}$, Mamady Diawara ${ }^{2}$, Cristiano M. Rossignoli ${ }^{3}$ and \\ Alexandros Gasparatos 1 \\ 1 Integrated Research System for Sustainability Sciences (IR3S), The University of Tokyo Institutes for \\ Advanced Studies (UTIAS), The University of Tokyo, Tokyo 113-8654, Japan; gasparatos@ir3s.u-tokyo.ac.jp \\ 2 Département de Technologie et Contrôle des Produits Alimentaires (TCPA), Institut Supérieur des Sciences \\ et Médecine Vétérinaire (ISSMV), Tangama 2, Dalaba BP 09, Guinea; mamadydiawara280@yahoo.fr \\ 3 WorldFish, Jalan Batu Maung, Batu Maung, 11960 Bayan Lepas, Penang, Malaysia, P.O. Box 500 GPO, \\ Penang 10670, Malaysia; c.rossignoli@cgiar.org \\ * Correspondence: siddighilonsin@gmail.com; Tel.: +81-90-8119-2890
}

Received: 31 January 2019; Accepted: 19 February 2019; Published: 22 February 2019

check for updates

\begin{abstract}
The Guinean government has promoted the large-scale production of industrial crops such as oil palm and rubber through the Guinean Oil Palm and Rubber Company (SOGUIPAH). Smallholder-based production of these crops has also been promoted to boost rural development but the food security outcomes are unclear. This exploratory study assesses the food security outcomes of smallholder-based oil palm and rubber production at the household level using six standardized metrics of food security. We compare households involved in industrial crop production and households that only grow food crops under subsistence conditions through statistical tools such as Propensity Score Matching (PSM) and Endogenous Treatment Effect Regression (ETER). Overall, results suggest that oil palm and rubber smallholders perform better than subsistence farmers on metrics that capture perceptions of hunger and coping behaviors but perform worse for food diversity metrics. We hypothesize that this discrepancy can possibly be explained by the strong sense of security that steady income provides across time, which outweighs the shortcomings of diet diversity. The results of this exploratory study can inform the development of more detailed assessments of the food security outcomes of interventions implemented by SOGUIPAH in the area (and the mechanism through which these impacts emerge).
\end{abstract}

Keywords: food consumption score (FCS); household food insecurity access scale (HFIAS); coping strategy index (CSI); industrial crops; Sub-Sahara Africa

\section{Introduction}

Industrial crops such as oil palm, rubber, sugarcane, cotton and jatropha, among others, have been promoted in several countries of Sub-Saharan Africa (SSA) [1-3]. Often these crops are promoted to boost rural development and alleviate poverty [2,4]. The recent surge in large-scale land acquisitions for industrial crops in SSA [5] has raised concerns about the effects of large-scale industrial crop expansion on local food security and rural livelihoods [6,7]. However, it is not always clear as to what extent (and under which conditions) industrial crop production improves or compromises rural livelihoods and household food security in SSA [8-10].

Wiggins et al. [1] have identified many mechanisms through which industrial crop production interacts with the different pillars of food security-namely food availability, access, stability, 
utilization. For example, agricultural projects that have commercialized industrial crops, such as sugarcane, oil palm, rubber and jatropha, have claimed extensive areas in many countries in SSA [11,12]. Such projects have often converted agricultural land and reduced the available land for food production [13-15]. Furthermore, involvement in industrial crop value chains has been shown to divert labor from family farms and food crop production, sometimes compromising local food availability $[1,16]$. On the other hand, waged employment in industrial crop plantations or smallholder-based industrial crop production can generate employment and income opportunities in rural areas of SSA $[10,17,18]$. Households can invest the obtained income to purchase food or improve farm productivity increasing the yields of food crops (e.g., [9]. However, plantation wages can be low, often marginally higher than the national minimum wage level [19]. Furthermore, some payment schemes and loan arrangements can reduce substantially the income that eventually reaches industrial crops smallholders (e.g., [20,21]. The above suggest the rather entangled nature of the mechanisms that link industrial crop production and household food security in SSA.

Guinea, like many other countries in SSA, has experienced a declining and re-surging interest in industrial crop production. Following the establishment of the Second Republic (in 1984) and the liberalization of the economic system (in 1985), there have been several attempts to promote the expansion of industrial crops such as coffee, rubber and oil palm [22,23]. In particular, since 1986 the national agricultural policy has emphasized the development of large export-oriented rubber and oil palm plantations. Currently the Guinean Oil Palm and Rubber Company (SOGUIPAH) is the largest rubber and oil palm producer in the country accounting for significant employment and income generation at the national and the local level (see Section 2.1). However, despite these economic benefits SOGUIPAH operations have been linked to substantial local environmental and socioeconomic impacts [24]. Although SOGUIPAH has used in its plantations (and promoted among its smallholders) improved oil palm varieties, most of the smallholder-based oil palm production in the country comes from natural oil palm groves of the Dura variety [25]. In fact, even tough such natural oil palm varieties and artisanal processing techniques have low productivity (and are considered antiquated), they still account for $80 \%$ of the total national production $[22,25,26]$. Rubber is another major industrial crop in the country and is produced both in large plantations (e.g., SOGUIPAH) and smallholders linked to large estates (Section 2.1) [27]. There is also a renewed interest in coffee and cocoa production in Yomou area but the production is still low compared to oil palm and rubber production.

At the same time, the government of Guinea as incorporated food security is a key policy goal in various national strategies and programs. These include the National Agricultural Development Plan (PNDA), the National Agriculture Investment and Food Security Plan (PNIASA) and the Poverty Reduction Strategy (PRS), among others. However, these policies do not explicitly make provisions on how to reduce any possible negative trade-offs between industrial crop production and food security. Currently there is no study in Guinea that attempts to capture the interactions between smallholder-based industrial crop production and household food security. The few existing studies on the impact of oil palm and rubber production have focused on some environmental and socioeconomic impacts (e.g., [24], rather than food security. It is important to establish a knowledge base in order to understand whether there is a competition between industrial crop production in the country and household food security.

This article aims to provide an exploratory assessment of the food security outcomes of involvement in smallholder-based rubber and oil palm production in Guinea. For this exploratory assessment we focus on a small sample of smallholders from communities around the SOGUIPAH estate in the Diecke sub-prefecture, Yomou prefecture. Considering the many industrial crop-related mechanisms that affect household food security, our rapid assessment employs complementary standardized metrics of food security [28-30], to compare the food security status of oil palm and rubber smallholders and smallholders not involved in industrial crop production. The selected metrics elucidate different aspects of food security related to diet diversity, perceptions of hunger and coping behaviors in the face of food scarcity [28-30]. Considering the relatively little literature empirically 
documenting the food security outcomes of involvement in industrial crop production, our exploratory study fills a major gap for Western Africa (and Guinea in particular). As such it can be used to inform the development of in-depth studies.

Section 2 outlines the methodology and study areas. Section 3 highlights the main results of the study focusing on the food security outcomes of involvement in industrial crop production. Section 4 puts the main findings into perspective and discusses the implications for Guinea and the limitations of this study.

\section{Methodology}

\subsection{Study Site}

This study was carried out in Diecke sub-prefecture (Figure 1), one of the seven sub-prefectures of the Yomou prefecture located in the N'Zerekore Administrative Region. Yomou covers an area of $3920 \mathrm{~km}^{2}$ and has an estimated population of 114,371 people. It is one of the few areas in Western Africa that still contains extensive areas of tropical rainforest. Its climate can be classified as sub-equatorial, with the mean temperature ranging from $18{ }^{\circ} \mathrm{C}$ in December to $22{ }^{\circ} \mathrm{C}$ in March and the mean annual rainfall is just over $2000 \mathrm{~mm}$. The wet season spans nine months and there is relatively high humidity throughout the year [23].
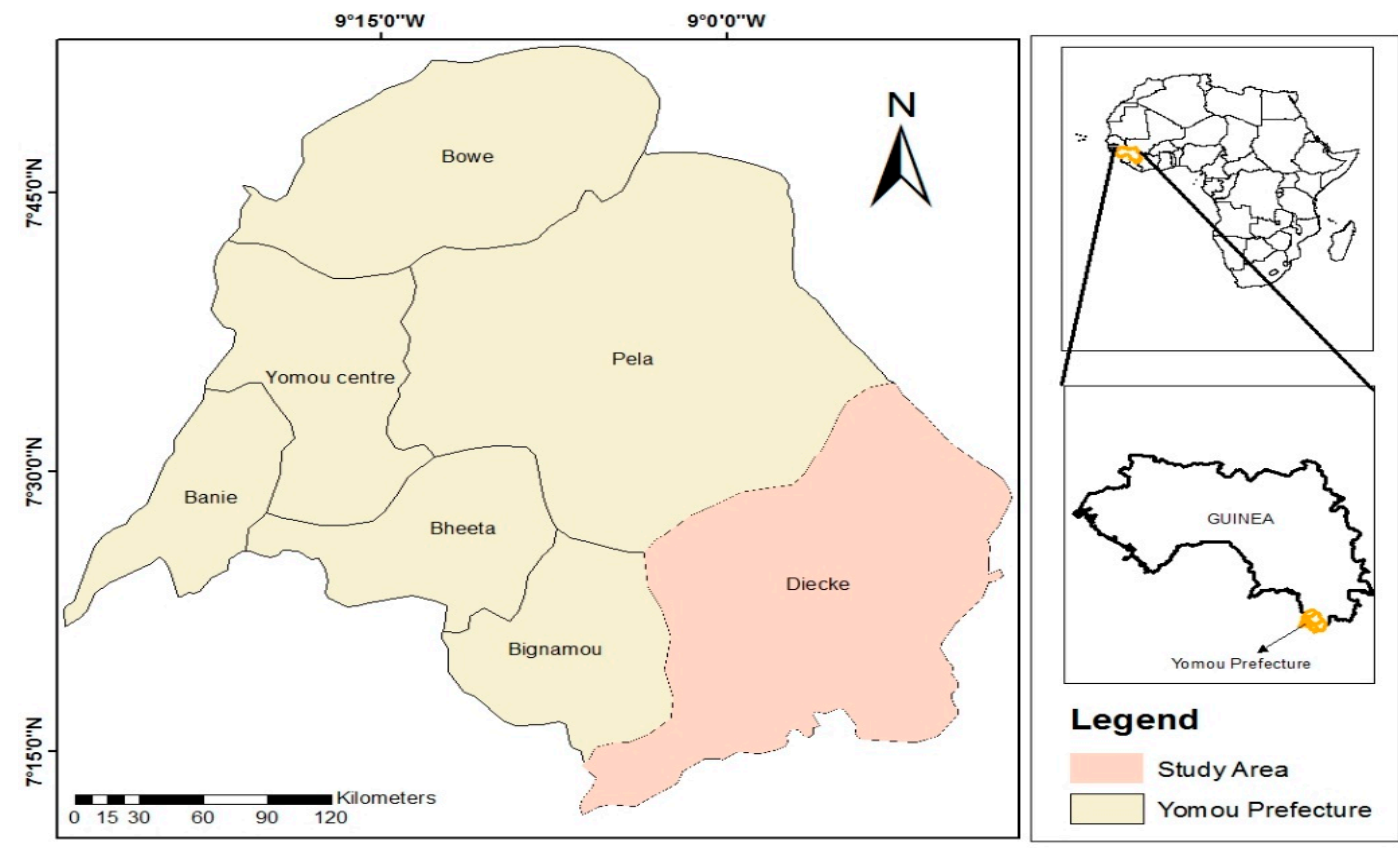

Figure 1. Location of study site.

Rubber and oil palm are the major industrial crops produced in the region, with coffee being less (but increasingly) popular (Section 1). Diecke accommodates some of the operations of the largest industrial crop company in Guinea, the Guinean Oil Palm and Rubber Company (SOGUIPAH). SOGUIPAH was founded in 1987 by the Guinean government with the mandate of undertaking the large-scale production of palm oil and rubber in the districts of Diecke and Bignamou and promoting it to local smallholders. To meet its mandate SOGUIPAH negotiated the acquisition of 22,830 ha of land from local communities against indemnities. SOGUIPAH currently operates rubber and oil palm core plantations that span approximately 10,000 ha, of which 7000 ha are under rubber and 3000 ha under oil palm. It also operates rice plantations, a palm oil mill and soap and curd (coagulated rubber) processing plants. SOGUIPAH is the largest company in Guinea with over 3500 employees, contributing significantly to the national economy and local communities. 
Between 1989 and 2002 through the support of several external donors, a contract-based farming scheme for oil palm and rubber production on family farms was developed in areas around the core plantations. At the same time lowland areas for irrigated rice production were developed. Farmers that agreed to produce irrigated rice for their own consumption were prioritized for inclusion to these schemes. In a sense this was to encourage local communities to abandon slash-and-burn practices responsible for deforestation in the area. Accordingly, the plots that were no longer used for rainfed rice production were planted with oil palm and rubber trees.

SOGUIPAH played a leading role in developing local capacity and infrastructure for smallholder-based oil palm and rubber production in the area. In particular SOGUIPAH provided the planting material (i.e., hybrid oil palm of the tenera variety, grafted rubber plants from various clones), organized the upstream aspects of the value chain (e.g., supply of agricultural inputs) and provided farmers with technical support. SOGUIPAH also provided training and advice for the appropriate maintenance and management of the smallholder plantations. At the same time, SOGUIPAH developed the lowland areas for rice cultivation and provided training, improved rice varieties and fertilizers for the first three years. SOGUIPAH also opened and maintains feeder roads for the collection of oil palm and rubber. The core plantations and factories are also significant employment options for many local communities, with some locals receiving middle-management positions.

SOGUIPAH chose the areas for the smallholder schemes based on two criteria: (a) clear land ownership/tenure and (b) favorable agro-ecological conditions. However, accessibility eventually became an important third criterion, with inclusion priority given to plots alongside the existing feeder roads. In order to develop the lowland rice areas, it was necessary for landowners to abandon their land. This land then redistributed between several farmers, including the original landowners. SOGUIPAH undertook plantation development and the plots were subsequently allocated to farmers on credit.

Contractual agreements between SOGUIPAH and smallholder farmers bind the latter to sell their entire oil palm and rubber production to SOGUIPAH. Smallholders are required to prepare the plot at their own expense but SOGUIPAH can provide loans for the planting material and agricultural inputs. Smallholders can also receive monetary compensation for the labor required to maintain the family rubber and oil palm plots.

Overall, approximately 1866 ha and 1760 ha were developed for smallholder-based oil palm and rubber production, respectively. An additional 1298 ha were developed for lowland irrigated rice production. About 4200 smallholders were linked with the different SOGUIPAH schemes in 2002 but due to the lack of public information it is not clear how many farmers are currently linked to these schemes.

\subsection{Data Collection}

To assess the food security outcomes of involvement in industrial crop production we conducted household surveys in the vicinity of SOGUIPAH estate in Diecke sub-prefecture. In particular we conducted household surveys in March 2016 with smallholders that cultivate rubber, oil palm and food crops (subsistence farmers).

The survey followed a multi-stage sampling approach. Firstly, based on expert interviews we selected three districts within Diecke, where the main livelihoods relate to subsistence crop cultivation (Baala district), rubber cultivation (Baghei district) and oil palm cultivation (Gbeipah district). Within each district we identified communities involved in the production of each crop and we selected randomly households through transect walks in the study communities. We used transect walks to identify responding households as it was not possible to secure lists of households engaging in these activities. In total we conducted 180 household surveys, of which 67 surveys targeted subsistence farmers, 76 rubber smallholders and 37 oil palm growers. Household interviews targeted either the household head or the spouse, whoever was available during the visit. Interviews were conducted in the local language using trained enumerators and were captured in hard copy questionnaires that 
were subsequently digitized after the end of the survey in the capital Conakry. In order to minimize non-sampling errors (and thus to improve the quality of the captured data) we followed the same quality-assurance procedures as other similar surveys conducted by members of the research team in other industrial crop settings of SSA [2].

To assess the food security levels of the respondent households we employed a series of standardized metrics, namely the Food Consumption Score (FCS), Household Food Insecurity Access Scale (HFIAS), Household Hunger Scale (HHS), Coping Strategies Index (CSI), Reduced Coping Strategies Index (rCSI) and the Months of Inadequate Household Food Provisioning (MIHFP) (Table 1). The selected metrics elucidate different aspects of food security related to diet diversity, perceptions of hunger and coping behaviors in the face of food scarcity [28-30] (see Table 1 for more details). Thus, they can allow for a rapid and robust assessment of different aspects of food security aspects at the household level [28]. Relying on multiple metrics is essential for multi-dimensional concepts such as food security [31], with such standardized metrics being increasingly used to assess food security impacts in industrial crop settings of SSA (e.g., [32-35]). Essentially such approaches can reduce the complexity (and increase the consistency) of food security assessments considering the multiple interacting mechanisms that that are often at play in such industrial crop settings of SSA, for example, $[1,8,9,36]$.

The household survey also included various independent variables that were used to describe the study groups and to explain the determinants of food security at the group level (Table 1). These variables were selected based on existing literature focusing on the multiple socioeconomic factors affecting rural household food security such as the gender of household head, family size, household income, household livelihoods, dependency ratio, (cultivated) land size and livestock ownership among others, for example, [33,37-39] among several other studies.

\subsection{Data Analysis}

Data was analyzed in four stages (Step 1-4), using a series of statistical tools. Step 1 compares the three study groups across the main household characteristics outlined in Table 1 . We use an independent $t$-test for the continuous variables as a means of comparing the different characteristics of the surveyed groups (Table 1). Step 2 assesses the household food security status using the standardized metrics described in Section 2.2. We provide both the mean value for each study group, as well as the distribution of respondents across the different levels of food security. Considering that the HHS and rCSI are derivatives of the HFIAS and CSI respectively (Table 1), we report their results in the Supplementary Electronic Material.

Table 1. Analytical variables and their definition.

\begin{tabular}{ll}
\hline \multicolumn{1}{c}{ Variables } & \multicolumn{1}{c}{ Definition and Measurement } \\
\hline Food consumption score (FCS) & Household Food Security Indicators \\
\hline Household food insecurity access scale (HFIAS) & $\begin{array}{l}\text { Composite measure of diet diversity. Includes } \\
\text { questions about the different food groups (and their } \\
\text { nutritional value) consumed by the household in the } \\
7 \text { days prior to the survey [40,41]. }\end{array}$ \\
& $\begin{array}{l}\text { Composite measure of perceptions of hunger. } \\
\text { Includes questions about the prevalence, acceptability } \\
\text { and anxiety over insecure access to food in the four } \\
\text { weeks prior to the survey [30,42,43]. }\end{array}$ \\
\hline Household hunger scale (HHS) & $\begin{array}{l}\text { Composite measure of perceptions of hunger. It } \\
\text { comprises the final three questions of the HFIAS, all } \\
\text { of which pertain to the consequences of severe food } \\
\text { insecurity [29]. }\end{array}$ \\
\hline
\end{tabular}


Table 1. Cont.

\begin{tabular}{|c|c|}
\hline Variables & Definition and Measurement \\
\hline Coping strategy index (CSI) & $\begin{array}{l}\text { Composite measure of coping attitudes during } \\
\text { periods of food insecurity. It contains questions about } \\
\text { the frequency and severity of behaviors in which } \\
\text { households engage when not having enough food or } \\
\text { enough money to buy food }[44,45] \text {. }\end{array}$ \\
\hline Reduced coping strategy index (rCSI) & $\begin{array}{l}\text { Composite measure of coping attitudes during } \\
\text { periods of food insecurity. It aggregates the five } \\
\text { (pre-weighted) coping strategies employed in } \\
\text { response to food shortages [44]. }\end{array}$ \\
\hline $\begin{array}{l}\text { Months of inadequate household food } \\
\text { provisioning (MIHFP) }\end{array}$ & $\begin{array}{l}\text { Number of months in the past year that a household } \\
\text { was not able to provide itself with enough food [46]. }\end{array}$ \\
\hline \multicolumn{2}{|c|}{ Household Characteristics } \\
\hline Household size & Number of persons living in the household \\
\hline Gender of household head & 1 = female-headed household, $0=$ otherwise \\
\hline Origin of respondent & $1=$ born in the community, $0=$ otherwise \\
\hline Dependency ratio & $\begin{array}{l}\text { Percentage: Ratio of dependent household members } \\
\text { (i.e., members younger than } 15 \text { or older than } 65 \text { ) to } \\
\text { household members of working age (i.e., } 15-65 \text { years) }\end{array}$ \\
\hline Off-farm income & $\begin{array}{l}\text { USD: Income related to off-farm activities, such as } \\
\text { casual work or selling woodland products }\end{array}$ \\
\hline Child mortality ratio & $\begin{array}{l}\text { Percentage: Ratio of children deceased, to the total } \\
\text { number of deceased members in the household }\end{array}$ \\
\hline Livestock ownership & $\begin{array}{l}\text { Tropical Livestock Unit (TLU): Aggregate measure of } \\
\text { livestock ownership calculated based on the number } \\
\text { of livestock species using conversion factors for } \\
\text { livestock in Sub-Sahara Africa countries. }\end{array}$ \\
\hline Total household income & USD: includes off-farm and farm income \\
\hline Monthly food expenditure & USD \\
\hline Amount borrowed to purchase food & USD \\
\hline \multicolumn{2}{|c|}{ Agricultural Characteristics } \\
\hline Ratio of land given to SOGUIPAH to current land (\%) & $\begin{array}{l}\text { Percentage: Ratio of the household cultivated land } \\
\text { that was given to SOGUIPAH to the current } \\
\text { cultivated land }\end{array}$ \\
\hline Size of cultivated land & ha \\
\hline Size of natural palm groves & ha \\
\hline
\end{tabular}

Note: 1 USD = 8900 GNF (Guinean Francs) as per exchange rate during data collection.

Step 3 uses the propensity score matching (PSM) approach in a binary treatment variable [47], to estimate the food security outcomes of involvement in smallholder-based rubber or oil palm production. Several recent studies have used the PSM approach to assess the impact of different agricultural interventions in Africa (e.g., see [38,48-51]. We use the three most commonly adopted matching methods, that is, neighbor matching (NNM), caliper-based matching (CBM) and the kernel-based matching (KBM) [52,53] (see Supplementary Electronic Material for more details). Due to unobservable differences between the participants and non-participants in industrial crop production, the PSM approach alone cannot conclusively elicit the impact of participation [52]. As all biases have not been controlled for, it is possible to overestimate or underestimate the food security outcomes of involvement in industrial crop production, eliciting erroneous conclusions. To avoid such complications, we perform the test of balancing [52]. Matching quality is checked through the examination of the standardized bias and $t$-Test. The standardized bias is a suitable indicator 
for assessing the distance in marginal distributions of the $\mathrm{X}$-variables [54]. For each covariate $\mathrm{X}$, the standardized bias is defined as the difference of sample means in the treated and not treated subsamples, as a percentage of the square root of the average of sample variances in both groups. One possible problem with the standardized bias approach is that it is not possible to obtain a clear indication of the success of the matching procedure, even though in most empirical studies a bias reduction below $3 \%$ or $5 \%$ is considered sufficient [53]. A similar approach uses a two-sample $t$-Test to check whether there are significant differences in covariate means for both groups [54]. Before matching differences are expected but after matching the covariates should be balanced in both groups and hence no significant differences should be found. The $t$-Test might be preferred if the analyst is concerned with the statistical significance of the results but bias reduction before and after matching is not clearly visible [53].

Step 4 uses the endogenous treatment effects regression (ETER) model to provide a consistent estimate of the outcomes of engagement in industrial crop production on the standardized metrics of food security. We estimate the Average Treatment Effect (ATE) of growing oil palm or rubber on food security using the "etregress" function at the Stata software. This function estimates an average treatment effect (ATE) and the other parameters of a linear regression model, augmented with an endogenous binary-treatment variable. Estimation is by either full maximum likelihood or a two-step consistent estimator. When there are no interactions between the treatment variable and the outcome covariates, the etregress function directly estimates the ATE and the ATET. The ATET is the same as the ATE in this case because the treatment indicator variable has not interacted with any of the outcome covariates. More details about the endogenous treatment effect regression (ETER) model are included in the Supplementary Electronic Material.

\subsection{Ethical Considerations}

The research protocol was developed as part of large study funded by the Belmont Forum and was based on a similar protocol that elicited the impact of industrial crops in southern Africa [2]. Similarly, for the development of the protocol of this study, we adopted the good practice recommendations of the UK Economic and Social Science Research Council (ESRC). The research protocol was reviewed and approved by the ethical review committee of the University of Tokyo (identification number 15-186). Approval was granted in December 2015, before fieldwork commencement.

To ensure smooth community entry, we undertook meetings with traditional authorities prior to initiating the household survey. This was necessary as local chiefs are influential members of local communities in Guinea. We sought oral informed consent from all respondents before each interview, as it was deemed as the most appropriate approach considering the high illiteracy rates in the local communities. We ensured that all respondents were fully aware about what their participation in this study entailed and explained any concerns related to anonymity and disclosure of personal information.

\section{Results}

\subsection{Household Characteristicss}

Table 2 compares the main household characteristics of the different study groups, that is, rubber smallholders, oil palm smallholders and subsistence farmers. Households that grow oil palm tend to be significantly larger than rubber growers and subsistence farmers. Both groups of industrial crop producers tend to have substantially lower child mortality than subsistence farmers. 
Table 2. Key household characteristics and differences between the study groups.

\begin{tabular}{|c|c|c|c|c|c|c|}
\hline Household Characteristics & $\begin{array}{c}\text { Rubber } \\
\text { Growers } \\
\text { (Group 1) }\end{array}$ & $\begin{array}{l}\text { Oil Palm } \\
\text { Growers } \\
\text { (Group 2) }\end{array}$ & $\begin{array}{c}\text { Subsistence } \\
\text { Farmers } \\
\text { (Group 3) }\end{array}$ & $\begin{array}{l}\text { Group } 1 \text { vs. } \\
\text { Group } 2\end{array}$ & $\begin{array}{l}\text { Group } 2 \text { vs. } \\
\text { Group } 3\end{array}$ & $\begin{array}{l}\text { Group } 1 \text { vs. } \\
\text { Group } 2\end{array}$ \\
\hline & \multicolumn{3}{|c|}{ Mean score (Standard deviation) } & \multicolumn{3}{|c|}{ (Mean difference) $p$-value } \\
\hline Dependency ratio $(\%)$ & $7.80(22.09)$ & $12.01(24.09)$ & $16.68(55.64)$ & $(-8.88) 0.202$ & $(-4.67) 0.629$ & $(-4.21) 0.358$ \\
\hline Off-farm income (USD) & $64.95(165.63)$ & $75.13(201.6)$ & $28.07(62.45)$ & (36.88) $0.088^{*}$ & (47.06) 0.080 * & $(-10.18) 0.776$ \\
\hline Adult mortality (number) & $2.28(1.76)$ & $1.82(1.29)$ & $2.68(1.91)$ & $(-0.40) 0.211$ & $(-0.86) 0.022 * *$ & $(0.46) 0.176$ \\
\hline Cultivated land (ha) & 7.17 (12.11) & $7.51(7.84)$ & $5.07(6.94)$ & (2.10) 0.213 & (2.43) $0.105^{*}$ & $(-0.33) 0.879$ \\
\hline Land given to SOGUIPAH (ha) & $17.50(39.63)$ & $28.95(97.66)$ & $23.79(44.26)$ & $(-6.29) 0.371$ & (5.15) 0.712 & $(-11.45) 0.378$ \\
\hline $\begin{array}{c}\text { Ratio of land given to SOGUIPAH } \\
\text { to current land }(\%)\end{array}$ & $446(1378)$ & $732.6(2469)$ & $1262(2557)$ & $(-815.67) 0.017^{* *}$ & $(-529) 0.309$ & $(-286.4) 0.430$ \\
\hline Home garden area (ha) & $3.25(6.98)$ & $4.56(9.48)$ & $3.31(3.48)$ & $(-0.05) 0.957$ & (1.25) 0.332 & $(-1.31) 0.410$ \\
\hline Natural palm grove area (ha) & $2.53(3.10)$ & $1.45(2.01)$ & $0.81(1.74)$ & (1.72) $0.000^{* * *}$ & $(0.64) 0.092 *$ & (1.08) 0.056 * \\
\hline Livestock (TLU) & $1.16(5.85)$ & $0.28(0.88)$ & $0.65(1.56)$ & $(0.513) 0.488$ & $(-0.37) 0.189$ & (0.88) 0.365 \\
\hline
\end{tabular}

Note: ${ }^{* * *} p<0.01 ;{ }^{* *} p<0.05 ;{ }^{*} p<0.1$.

Oil palm growers have slightly larger cultivated land areas compared to rubber growers (7.51 vs. $7.17 \mathrm{ha}$ ), with the cultivated land of both groups of industrial crop growers being significantly larger than that of subsistence farmers. Oil palm growers have given on average more land to SOGUIPAH (28.95 ha), followed by subsistence farmers (23.79 ha) and rubber growers (17.50 ha). Both groups of industrial crop growers tend to have access to larger areas of semi-wild oil palm groves compared to subsistence farmers.

All groups derive most of their income from farming activities, with some minor income coming from off-farm activities such as casual work. Oil palm growers have the highest overall income (USD 1406), followed by rubber growers (USD 754) and subsistence farmers (USD 422). Both groups of industrial crop growers tend to spend more money to buy food but at the same time they borrow less for food purchases compared to subsistence farmers. The above suggest the large importance of oil palm and rubber production for rural in the study areas.

\subsection{Food Security Status}

Both groups of industrial crop smallholders have significantly lower FCS $(p<0.01)$ (and hence lower food security) compared to irrigated farmers (Table 3). Patterns for the HFIAS are quite different, with both industrial crop smallholder groups registering lower HFIAS (and hence higher food security) compared to subsistence farmers but this difference is statistically significant only for oil palm growers $(p<0.01)$ but all three groups have very similar levels of CSI, with no statistically significant differences between them (Table 3). Interestingly there is some variation in the levels of the reduced versions of the HFIAS and CSI (HHS and rCSI respectively). HHS levels improve for subsistence farmers and become very similar to those of oil palm and rubber growers but rCSI levels do not change compared to the patterns observed for the full version of the metric (see Table S1 and Figure S1, Supplementary Electronic Material). On average subsistence farmers experience the fewest months of inadequate food provisioning (2.24 months), compared to rubber ( 2.64 months) and oil palm growers (3.30 months). However, these differences are only statistically significant between the subsistence farmers and oil palm growers $(p<0.05)$. 
Table 3. Mean food security indicator scores and differences between study groups.

\begin{tabular}{ccccccc}
\hline Metrics & $\begin{array}{c}\text { Rubber } \\
\text { Growers } \\
\text { (Group 1) }\end{array}$ & $\begin{array}{c}\text { Oil Palm } \\
\text { Growers } \\
\text { (Group 2) }\end{array}$ & $\begin{array}{c}\text { Subsistence } \\
\text { Farmers } \\
\text { (Group 3) }\end{array}$ & $\begin{array}{c}\text { Group 1 vs. } \\
\text { Group 2 }\end{array}$ & $\begin{array}{c}\text { Group 2 vs. } \\
\text { Group 3 }\end{array}$ & $\begin{array}{c}\text { Group 1 vs. } \\
\text { Group 2 }\end{array}$ \\
\hline \multicolumn{7}{c}{ Mean score (Standard deviation) } \\
\hline FCS & $35.03(21.42)$ & $34.43(22.51)$ & $45.18(19.83)$ & $(-10.15) 0.004^{* * *}$ & $(-10.75) 0.013^{* * *}$ & $(0.59) 0.892$ \\
HFIAS & $10.53(6.68)$ & $7.78(5.61)$ & $11.37(6.02)$ & $(-0.85) 0.430$ & $(-3.59) 0.004^{* * *}$ & $(2.74) 0.033^{* *}$ \\
CSI & $30.53(33.12)$ & $40.51(38.07)$ & $32.75(32.18)$ & $(-2.22) 0.686$ & $(7.77) 0.273$ & $(-9.99) 0.115$ \\
MIHFP & $2.64(2.51)$ & $3.30(2.63)$ & $2.24(1.83)$ & $(0.41) 0.277$ & $(1.06) 0.018^{* *}$ & $(-0.65) 0.204$ \\
\hline
\end{tabular}

Figure 2 provides a more disaggregated view for the different food security metrics (see also Table S1 /Figure S1, Supplementary Electronic Material). In particular, they outline the proportion of respondents who are food secure and food insecure within each study group. In terms of the FCS, $29.7 \%$ of oil palm growers, $46.6 \%$ of rubber growers and $59.7 \%$ of subsistence farmers are food secure (i.e., falling within the "Acceptable" category) (Figure 2). Thus, in terms of diet diversity $53.4 \%$ of rubber growers and a whopping $70.3 \%$ of oil palm growers are food insecure (i.e., "Borderline" and "Poor"). In terms of HFIAS, only $4.3 \%$ and $9.0 \%$ of rubber growers and the subsistence farmers are food secure (either "Secure" or "Mildly Food Insecure"). No oil palm grower falls in the food secure and mildly food insecure categories, suggesting the widespread perceptions of hunger for this group (Figure 2). When using the CSI only $43.4 \%, 37.8 \%$ and $38.8 \%$ of rubber growers, oil palm growers and subsistence farmers respectively are food secure (i.e., fall in the "Secure" and "Mildly Food Insecure" categories). Similar patterns also emerged for the reduced versions of these metrics (i.e., HHS, rCSI) (see Table S2, Supplementary Electronic Material).

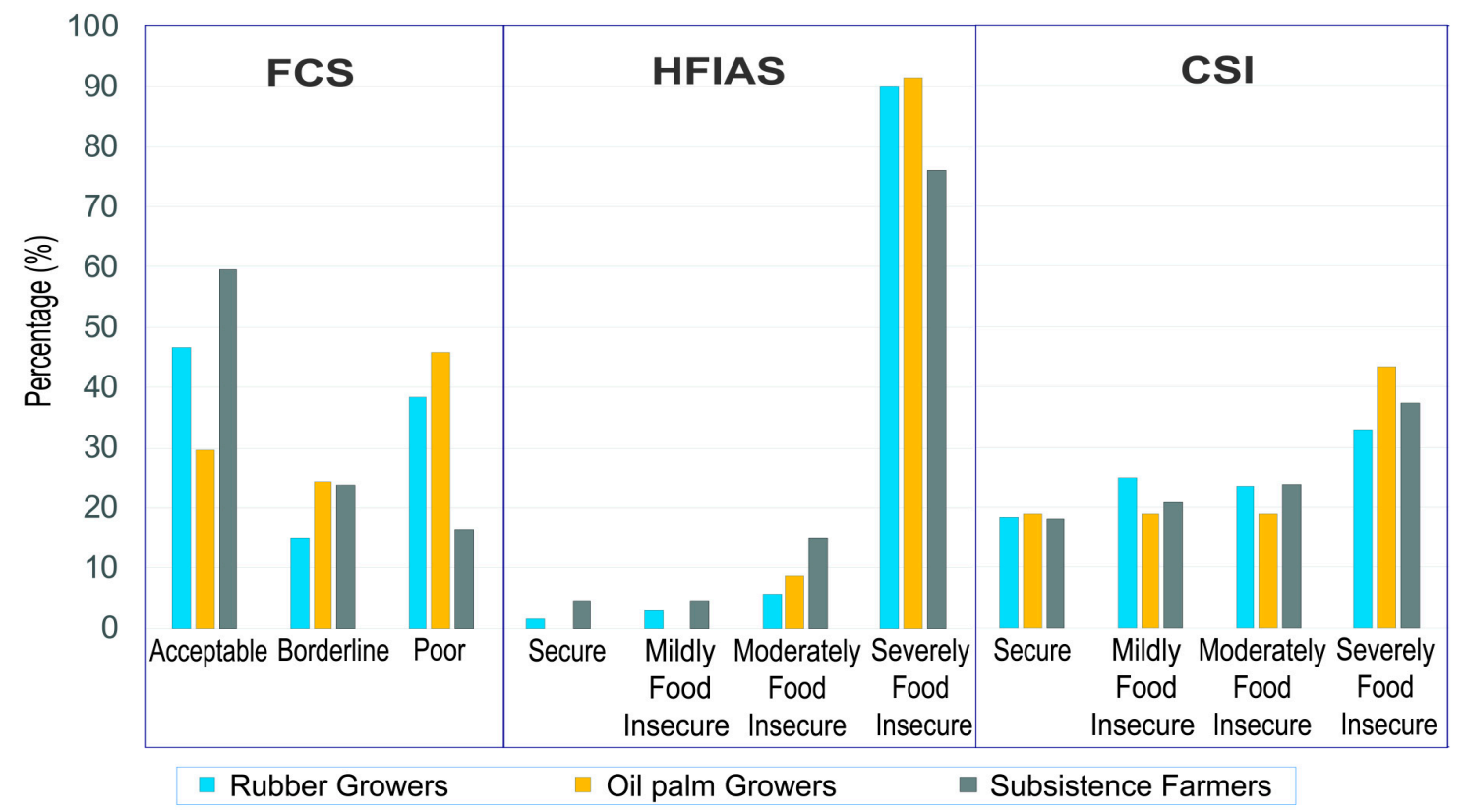

Figure 2. Respondent distribution across food security thresholds for the different metrics.

The above suggests that with only a few exceptions, most of the surveyed households can be classified as food insecure for most food security metrics. Overall for the FCS and HFIAS fewer subsistence farmers are classified as food insecure, compared to rubber and oil palm growers. On the contrary for CSI a higher proportion of subsistence farmers are food insecure, compared to both groups of industrial crop growers. This suggests that regardless of involvement in industrial crop production, the local communities experience extensive food insecurity. 


\subsection{Food Security Outcomes of Involvement in Industrial Crop Production}

\subsubsection{Propensity Score Matching}

To understand the food security outcomes of involvement in oil palm and rubber production, we estimate the average difference of the Average Treatment Effect on the Treated (ATT). First we identify the determinants of involvement in industrial crop production (Table S3, Supplementary Electronic Material) and then use the NNM, CBM and KBM matching methods for the different food security metrics (Section 2.3) related to dietary diversity (FCS), perceptions of food insecurity (i.e., HFIAS) and coping behaviors (i.e., CSI) (Table 4).

For the FCS, the ATT difference of involvement in rubber production is: $15.8,-19.13$ and -6.99 points for the NNM, CBM and KBM methods, respectively. The CBM matching method gives the only statistically significant difference $(p<0.05)$ (Table 4). The ATT difference for involvement in oil palm production is $21.49,-7.60$ and 27.82 points for the NNM, CBM and KBM methods respectively, with the NNM and KBM estimating statistically significant differences $(p<0.1)$ (Table 4$)$. The above suggests that participation in rubber production could reduce diet diversity (and as extent food security), while involvement in oil palm production has the opposite effect. However, in the latter case the statistical significance is quite low, so caution needs to be exercised when considering this finding.

For the HFIAS the ATT difference of involvement in rubber production is $-6.01,-0.95$ and -2.28 points for the NNM, CBM and KBM methods, respectively. Of these ATT differences estimated through NNM and KBM are statistically significant $(p<0.1)$ (Table 4$)$. When it comes to involvement in oil palm production, the ATT difference for all matching methods indicates a negative and significant effect for both the HFIAS $(p<0.05)$.

The above findings suggest that involvement in rubber and oil palm smallholder production leads to a decrease of the food insecurity related experiential measures (HFIAS), which means a subsequent increase in food security. However, the outcomes for oil palm are stronger, more significant and more consistent between the matching techniques, compared to rubber growers.

For the coping strategies measure, most matching tests suggest that involvement in rubber and oil palm production reduces the CSI, which implies an increase in food security. However, in almost all cases the ATT differences are either not statistically significant or have a low level of significance (Table 4).

Table 4. Impact of participation in industrial crop production on food security metrics.

\begin{tabular}{|c|c|c|c|c|c|c|c|c|}
\hline \multirow[b]{2}{*}{ Parameters } & \multicolumn{4}{|c|}{ Rubber Growers vs. Subsistence Farmers } & \multicolumn{4}{|c|}{ Oil Palm Growers vs. Subsistence Farmers } \\
\hline & Treated & Untreated & Difference (S.E) & T-stat & Treated & Untreated & Difference (S.E) & T-stat \\
\hline \multicolumn{9}{|c|}{ NNM } \\
\hline Unmatched & 35.03 & 45.18 & $-10.15(3.47)$ & -2.93 & 34.43 & 45.18 & $-10.75(4.26)$ & -2.52 \\
\hline ATT & 35.03 & 19.22 & $15.80(14.41)$ & 1.10 & 34.43 & 12.95 & $21.49(13.48)$ & $1.59 *$ \\
\hline \multicolumn{9}{|c|}{ CBM } \\
\hline Unmatched & 35.03 & 45.18 & $-10.15(3.47)$ & -2.93 & 34.43 & 45.18 & $-10.75(4.26)$ & -2.52 \\
\hline ATT & 33.68 & 52.80 & $-19.13(8.07)$ & $-2.37^{* *}$ & 22.80 & 30.40 & $-7.60(14.95)$ & -0.51 \\
\hline \multicolumn{9}{|c|}{ KBM } \\
\hline Unmatched & 35.03 & 45.18 & $-10.15(3.47)$ & -2.93 & 34.43 & 45.18 & $-10.75(4.26)$ & -2.52 \\
\hline ATT & 32.78 & 39.77 & $-6.99(5.98)$ & -1.17 & 37.19 & 9.37 & $27.82(17.43)$ & $1.60 *$ \\
\hline \multicolumn{9}{|c|}{$\begin{array}{c}\text { HFIAS } \\
\text { NNM }\end{array}$} \\
\hline Unmatched & 10.53 & 11.37 & $-0.85(1.07)$ & -0.79 & 7.78 & 11.37 & $-3.59(1.20)$ & -2.98 \\
\hline ATT & 10.53 & 16.54 & $-6.01(4.15)$ & $-1.45^{*}$ & 7.78 & 16.62 & $-8.84(4.39)$ & $-2.01^{* *}$ \\
\hline
\end{tabular}


Table 4. Cont.

\begin{tabular}{|c|c|c|c|c|c|c|c|c|}
\hline \multirow[b]{2}{*}{ Parameters } & \multicolumn{4}{|c|}{ Rubber Growers vs. Subsistence Farmers } & \multicolumn{4}{|c|}{ Oil Palm Growers vs. Subsistence Farmers } \\
\hline & Treated & Untreated & Difference (S.E) & T-stat & Treated & Untreated & Difference (S.E) & T-stat \\
\hline \multicolumn{9}{|c|}{ CBM } \\
\hline Unmatched & 10.53 & 11.37 & $-0.85(1.07)$ & -0.79 & 7.78 & 11.37 & $-3.59(1.20)$ & -2.98 \\
\hline ATT & 10.40 & 11.35 & $-0.95(2.27)$ & -0.42 & 4.60 & 11.60 & $-7.00(3.14)$ & $-2.23 * *$ \\
\hline \multicolumn{9}{|c|}{ КВM } \\
\hline Unmatched & 10.53 & 11.37 & $-0.85(1.07)$ & -0.79 & 7.78 & 11.37 & $-3.59(1.20)$ & -2.98 \\
\hline ATT & 10.25 & 12.53 & $-2.28(1.70)$ & -1.34 * & 8.32 & 17.52 & $-9.20(5.24)$ & $-1.75 * *$ \\
\hline \multicolumn{9}{|c|}{$\begin{array}{c}\text { CSI } \\
\text { NNM }\end{array}$} \\
\hline Unmatched & 30.53 & 32.75 & $-2.22(5.48)$ & -0.41 & 40.51 & 32.75 & $7.77(7.04)$ & 1.10 \\
\hline ATT & 30.53 & 59.38 & $-28.86(18.14)$ & $-1.59 *$ & 40.51 & 60.73 & $-20.22(29.42)$ & -0.69 \\
\hline \multicolumn{9}{|c|}{ CBM } \\
\hline Unmatched & 30.53 & 32.75 & $-2.22(5.48)$ & -0.41 & 40.51 & 32.75 & $7.77(7.04)$ & 1.10 \\
\hline ATT & 28.00 & 25.60 & $2.40(10.16)$ & 0.24 & 56.00 & 32.60 & $23.40(30.50)$ & 0.77 \\
\hline \multicolumn{9}{|c|}{ КВM } \\
\hline Unmatched & 30.53 & 32.75 & $-2.22(5.48)$ & -0.41 & 40.51 & 32.75 & $7.77(7.04)$ & 1.10 \\
\hline ATT & 27.72 & 33.11 & $-5.39(9.38)$ & -0.57 & 39.68 & 69.42 & $-29.74(28.31)$ & -1.05 \\
\hline
\end{tabular}

As outlined in Section 2.3 matching quality can be checked through the examination of the standardized bias (SB) and $t$-Test. Both approaches and particularly the latter, suggest good matching quality for the rubber and subsistence farmers (Table S5, Supplementary Electronic Material). For all comparison (i.e., rubber growers vs. subsistence farmers and palm oil growers vs. irrigated subsistence farmers) our results indicate that the matching quality obeys to the rules with the covariate income. Furthermore, a visual inspection of the density distributions of the estimated propensity scores for the compared groups indicates that the common support condition is satisfied, that is, there is a substantial overlap in the distribution of the propensity scores of both groups of industrial crop producers and subsistence farmers (Figures S2-S3, Supplementary Electronic Material).

\subsubsection{Endogenous Treatment Regression Model}

The estimated ATE of involvement in smallholder-based rubber production is -32.97 points for the measure of dietary diversity (i.e., the FCS). This implies that involvement in rubber production significantly reduces the FCS, having a substantial negative effect on food security. On the other hand, participation in rubber production reduces the experiential measure of food insecurity (i.e., HFIAS by -9.61 points) and the measure of coping behaviors (i.e., CSI by -52.65 points) (Table 5).

The estimated ATE of involvement in oil palm production is -22.04 points for the dietary diversity metric (i.e., FCS), suggesting a statistically significant decrease in this metric of food security (Table 6). Involvement in oil palm production reduces the experiential measures of food insecurity (HFIAS by -9.77 points) and consumption behaviors (CSI by -0.95 points). However, only the results for HFIAS are statistically significant (Table 6). 
Table 5. Linear Regression with Endogenous Treatment Effects for participation in rubber production.

\begin{tabular}{|c|c|c|c|}
\hline Outcome Equation & FCS & HFIAS & CSI \\
\hline & \multicolumn{3}{|c|}{ Coefficient (Standard Error) } \\
\hline Household size & $0.99 * * *(0.30)$ & $0.21 * *(0.10)$ & $-0.46(0.53)$ \\
\hline Ratio of land given to SOGUIPAH to current land & $0.0002(0.001)$ & 7E-05 (0.0003) & $-0.002(0.001)$ \\
\hline Home garden area & $0.09(0.27)$ & $0.08(0.09)$ & $-0.05(0.47)$ \\
\hline Natural palm grove area & $2.70^{* * *}(0.61)$ & $0.28(0.20)$ & $1.73 *(1.03)$ \\
\hline Livestock & $-0.29(0.34)$ & $-0.04(0.11)$ & $1.11 *(0.59)$ \\
\hline Annual food expenditure & $0.003^{* *}(0.002)$ & $0.0001(0.001)$ & $0.001(0.003)$ \\
\hline Amount borrowed for food & $-0.02(0.01)$ & $0.01 * *(0.004)$ & $-0.01(0.02)$ \\
\hline Origin of respondent & $-0.24(5.09)$ & $-0.03(1.89)$ & $10.50(9.82)$ \\
\hline Gender of household head & $2.64(3.76)$ & $-0.03(1.40)$ & $1.40(7.27)$ \\
\hline Participation in industrial crop production ( $1=$ Rubber, $0=$ Subsistence $)$ & $-32.97^{* * *}(9.18)$ & $-9.61^{* * *}(3.50)$ & $-52.65^{* * *}(11.87)$ \\
\hline Constant & $44.73 * * *(6.07)$ & $13.03^{* * *}(2.29)$ & $49.14^{* * *}(10.59)$ \\
\hline Origin of respondent & $0.50(0.33)$ & $0.47(0.32)$ & $0.49(0.31)$ \\
\hline Gender of household head & $0.02(0.25)$ & $0.06(0.25)$ & $-0.03(0.24)$ \\
\hline Constant & $-0.81^{* *}(0.35)$ & $-0.73^{* *}(0.34)$ & $-0.71^{* *}(0.33)$ \\
\hline /athrho & $0.59 *(0.33)$ & $1.01^{* *}(0.44)$ & $0.995^{* * *}(0.27)$ \\
\hline /lnsigma & $2.96^{* * *}(0.11)$ & $1.98(0.15)$ & $3.63^{* * *}(0.11)$ \\
\hline rho & $0.53(0.24)$ & $0.77(0.18)$ & $0.76(0.12)$ \\
\hline sigma & $19.35(2.12)$ & $7.27(1.09)$ & $37.83(4.04)$ \\
\hline lambda & $10.23(5.59)$ & $5.58(2.11)$ & $28.74(7.13)$ \\
\hline Number of observations & 143 & 143 & 143 \\
\hline Wald chi2(12) & $55.73 * * *$ & $31.67 * * *$ & $30.48 * * *$ \\
\hline Log likelihood & -706.41 & & -784.44 \\
\hline
\end{tabular}

Notes: ${ }^{* * *} p<0.01 ;{ }^{* *} p<0.05 ;{ }^{*} p<0.1$. Results for HHS and rCSI are included in Table S6, Supplementary Electronic Material.

Table 6. Linear Regression with Endogenous Treatment Effects for participation in oil palm production.

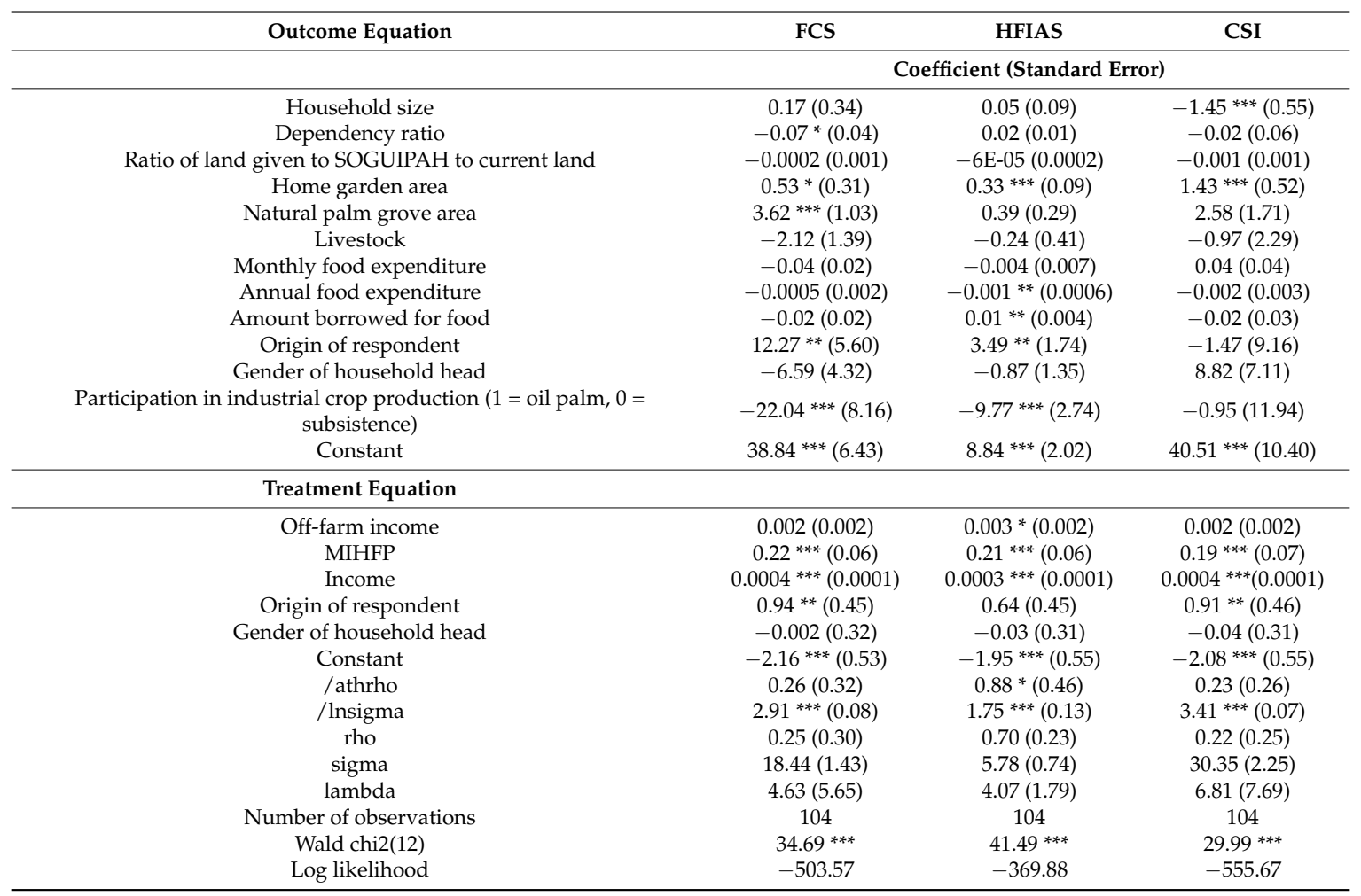

Notes: ${ }^{* * *} p<0.01 ;{ }^{* *} p<0.05 ;{ }^{*} p<0.1$. Results for HHS and rCSI are included in Table S7, Supplementary Electronic Material. 


\section{Discussion}

The studied local communities experience high levels of food insecurity, as consistently suggested by: (a) the mean scores of each food security metric (Table 3) and (b) the distribution of respondents across food security thresholds (Figure 2). However, the involvement in smallholder-based rubber and oil palm cultivation generates significantly higher on-farm income and allows industrial crop smallholders spend on average more money to purchase food (Section 3.1). Yet, the relatively larger family sizes of industrial crop grower households can possibly negatively affect their food security, as study groups with smaller average family size (e.g., subsistence farmers) report fewer months of inadequate household food provisioning (MIHFP) (Section 3.1). This finding reflects other studies in SSA, which have found that household size negatively affects some food security aspects [55-59].

Overall the food security status of study groups varies among the different metrics (Table 3). Both oil palm and rubber smallholders have significantly lower levels of diet diversity (FCS) than subsistence farmers (Table 3). On the other hand, industrial crop smallholders have lower levels of perceptions of hunger (HFIAS) compared to subsistence farmers, with oil palm growers having significantly better HFIAS levels than the other study groups. When it comes to coping behaviors in periods of food scarcity (e.g., CSI) there are mixed results between groups. In particular group differences are not statistically significant (Table 3). When looking at the distribution patterns across indicator thresholds (Table S1, Figure 2), subsistence farmers have the lowest proportion of respondents in the highest food insecurity thresholds for FCS and HFIAS and the second lowest for CSI (only behind rubber growers). Oil palm growers consistently have the highest proportion of respondents in the highest food insecurity thresholds for all indicators.

Both the PSM and ETER analyses suggest that involvement in industrial crop production decreases food security in terms of diet diversity (i.e., FCS) (Table 7). When it comes to perceptions of hunger (HFIAS), the involvement in oil palm production improves food security as indicated by both the PSM and ETER methods (Table 7). The PSM analysis reports similar findings and for rubber producers, albeit with lower (or no) statistical significance (Table 7).

On the other hand, it is not possible to conclusively deduce the effect of involvement in industrial crop production on coping behaviors (CSI). Although involvement in oil palm and rubber production seems to improve the CSI across most of the techniques, there are some contradictions in the results (i.e., when using the CBM matching technique or comparing the results of the PSM and the ETER methods) (Table 7). Hence, it is not easy to establish a causal relationship between involvement in industrial crop production and CSI improvement. It is worth mentioning, however, that the results of the ETER are statistically significant and suggest that involvement in industrial crop production improves the CSI and thus enhances food security.

Overall, Table 7 suggests that involvement in rubber and oil palm production largely enhances the levels of food security metrics that have longer time scales and entail a subjective awareness of food security, such as perceptions of hunger (HFIAS) and coping behaviors (CSI). On the other hand, involvement in oil palm and rubber production reduces the levels of food security metrics that use shorter time scales and measure food diversity (FCS). In this sense involvement in industrial crop production does not enhance consistently food security across all metrics. This effect can possibly be explained by the strong sense of security that steady and higher income provides across time (food stability), that outweighs the shortcomings on diet diversity (food utilization). 
Table 7. Food security outcomes of involvement in industrial crop cultivation for all metrics and tests.

\begin{tabular}{|c|c|c|c|c|c|}
\hline \multirow{2}{*}{ Analysis } & \multirow{2}{*}{ Metric/Test } & \multicolumn{2}{|c|}{ Rubber Grower vs. Subsistence Farmers } & \multicolumn{2}{|c|}{ Oil palm Growers vs. Subsistence Farmers } \\
\hline & & Effect on Metric & Comment & Effect on Metric & Comment \\
\hline \multirow{12}{*}{ PSM } & FCS & & & & \\
\hline & NNM (ATT) & $15.80(14.41)$ & $\begin{array}{l}\text { Positive effect on food } \\
\text { security (not significant) }\end{array}$ & $21.49 *(13.48)$ & $\begin{array}{c}\text { Positive effect on food } \\
\text { security (low significance) }\end{array}$ \\
\hline & CBM (ATT) & $-19.13 * *(8.07)$ & $\begin{array}{l}\text { Negative effect on food } \\
\text { security (significant) }\end{array}$ & $-7.60(14.95)$ & $\begin{array}{l}\text { Negative effect on food } \\
\text { security (not significant) }\end{array}$ \\
\hline & KBM (ATT) & $-6.99(5.98)$ & $\begin{array}{l}\text { Negative effect on food } \\
\text { security (not significant) }\end{array}$ & $27.82 *(17.43)$ & $\begin{array}{c}\text { Positive effect on food } \\
\text { security (low significance) }\end{array}$ \\
\hline & HFIAS & & & & \\
\hline & NNM (ATT) & $-6.01 *(4.15)$ & $\begin{array}{c}\text { Positive effect on food } \\
\text { security (low significance) }\end{array}$ & $-8.84^{* *}(4.39)$ & $\begin{array}{l}\text { Positive effect on food } \\
\text { security (significant) }\end{array}$ \\
\hline & CBM (ATT) & $-0.95(2.27)$ & $\begin{array}{l}\text { Positive effect on food } \\
\text { security (not significant) }\end{array}$ & $-7.00 * *(3.14)$ & $\begin{array}{l}\text { Positive effect on food } \\
\text { security (significant) }\end{array}$ \\
\hline & KBM (ATT) & $-2.28 *(1.70)$ & $\begin{array}{c}\text { Positive effect on food } \\
\text { security (low significance) }\end{array}$ & $-9.20 * *(5.24)$ & $\begin{array}{l}\text { Positive effect on food } \\
\text { security (significant) }\end{array}$ \\
\hline & CSI & & & & \\
\hline & NNM (ATT) & $-28.86 *(18.14)$ & $\begin{array}{c}\text { Positive effect on food } \\
\text { security (low significance) }\end{array}$ & $-20.22(29.42)$ & $\begin{array}{l}\text { Positive effect on food } \\
\text { security (not significant) }\end{array}$ \\
\hline & CBM (ATT) & $2.40(10.16)$ & $\begin{array}{l}\text { Negative effect on food } \\
\text { security (not significant) }\end{array}$ & $23.40(30.50)$ & $\begin{array}{l}\text { Negative effect on food } \\
\text { security (not significant) }\end{array}$ \\
\hline & KBM (ATT) & $-5.39(9.38)$ & $\begin{array}{l}\text { Positive effect on food } \\
\text { security (not significant) }\end{array}$ & $-29.74(28.31)$ & $\begin{array}{l}\text { Positive effect on food } \\
\text { security (not significant) }\end{array}$ \\
\hline \multirow{6}{*}{ ETER } & FCS & & & & \\
\hline & ATE & $-32.97^{* * *}(9.18)$ & $\begin{array}{l}\text { Negative effect on food } \\
\text { security (significant) }\end{array}$ & $-22.04 * * *(8.16)$ & $\begin{array}{l}\text { Negative effect on food } \\
\text { security (significant) }\end{array}$ \\
\hline & HFIAS & & & & \\
\hline & ATE & $-9.61^{* * *}(3.50)$ & $\begin{array}{l}\text { Positive effect on food } \\
\text { security (significant) }\end{array}$ & $-9.77^{* * *}(2.74)$ & $\begin{array}{l}\text { Positive effect on food } \\
\text { security (significant) }\end{array}$ \\
\hline & CSI & & & & \\
\hline & ATE & $-52.65 * * *(11.87)$ & $\begin{array}{l}\text { Positive effect on food } \\
\text { security (significant) }\end{array}$ & $-0.95(11.94)$ & $\begin{array}{l}\text { Positive effect on food } \\
\text { security (not significant) }\end{array}$ \\
\hline
\end{tabular}

However, this income can be precarious due to various reasons. For example, informal interviews with community members during this survey suggest that smallholders are contractually obliged to sell all their produce to SOGUIPAH. However, the company imposes its own pricing system, excluding the opinions of rubber and oil palm smallholders in price negotiations. Moreover, SOGUIPAH does not always respect signed agreements with smallholders or offer the agreed price. It is worth mentioning that international commodity prices have fluctuated widely in the past years but even during times of favorable international prices, SOGUIPAH has declined to increase the price offered for rubber coagulum and fresh fruit bunches (FFB). Many of the interviewed oil palm and especially rubber smallholders stated that their income has declined substantially in the past years due to this situation. This has brewed a growing dissatisfaction to rubber and oil palm smallholders in the wider study area.

Due to this situation, some community members and key stakeholders initiated the Regional Federation of Oil Palm and Rubber Producers (FEREPPAH). FEREPPAH is a farmer-led organization founded in 2006 in Diecke. Its main goal is to facilitate access to quality planting material, defend the interests of rubber and oil palm smallholders and strengthen their technical capability. FEREPPAH is managed directly by smallholders and, among others, it defends the rights of producers to sell their product in whatever market channel they chose, even if it is not SOGUIPAH. This has caused some conflicts with SOGUIPAH (which is essentially a for-profit entity) that can possibly affect the future stability of the oil palm/rubber market and the income that eventually reaches industrial crop smallholders. 
Such issues have been raised and in other studies in Guinea and the wider region. For example, the Famine Early Warning Systems Network (FEWS Net) has found that rubber remains an important cash crop in Guinea, despite the current production decline, low world market price and the lack of proper maintenance in many rubber plantations [60]. Actually, many rubber-producing households have diverted much of their effort and resources on food crop production in order to compensate for the lower incomes obtained through the rubber production [60]. The declining global rubber prices during the past few years have become a major obstacle to the expansion of smallholder-based rubber production in some parts of Guinea [61]. Even the rally in global rubber prices in the first half of 2016 (from 2000 GNF per kg in early 2016, to 2500 GNF per kg in July 2016) was not much of an incentive to further invest in rubber production and/or the maintenance of rubber farms [61]. Similar reports from Liberia have indicated that the steady decline in international rubber prices has influenced many rubber-producing households to turn to charcoal production, migration, remittances and borrowing, to meet their basic non-food expenditure [62].

As noted above involvement in industrial crop production has different effects for the different metrics used in this study. For example, subsistence farmers seem to be more food secure in terms of diet diversity (FCS), while rubber and oil palm smallholders to be better off in terms of perceptions of hunger (HFIAS) and coping behaviors (CSI), however, with the latter two less pronounced. This discrepancy between metrics suggests that they capture different aspects of food security and reflects several other studies that have raised issues of comparability between the different metrics (e.g., [30,31,39,63]. Our study also reflects some of the studies that have shown variability between standardized metrics of food security in industrial crop settings depending on the crop and type of involvement, (e.g., Thornhill et al., 2016; Anderman et al., 2014; Johnson et al., 2018). Considering this lack of consensus, it is important to continue building this current evidence base in SSA countries [1], especially in countries such as Guinea that experience both a renewed interest in industrial crop production and extensive food insecurity.

However, it is important to point some shortcoming of this study. First, as this is an exploratory rapid assessment, we used small samples for each study group. Even though we randomized to the extent possible sample selection, the fact remains that the small sample might have caused some of the inconclusive or contradictory results between some groups and tests. Future studies should aim to increase sample sizes in order to achieve a more robust statistical analysis. Second, our study included subsistence farmers as a non-intervention group. Even though the households in this group were not treated in terms of industrial crop adoption, there is a likelihood of interaction with other SOGUIPAH activities such as irrigation systems (for rice production) and road infrastructure. These are large-scale interventions that might have had some effect to the subsistence farmers. In this respect subsistence farmers might not have been a control group in the very strict sense of the term (this is why we do not use this term in this study). Even though this does not affect the main focus of the analysis (i.e., food security outcomes of involvement in industrial crop production), future studies should seek to include control groups that did not have any interaction with SOGUIPAH. This would possibly require locating control groups in faraway communities to ensure that SOGUIPAH activities did not have any effect on them. In such studies caution should be paid to find communities that have exactly the same characteristics (or shared the exact circumstances) of the industrial crop growers prior to interaction with SOGUIPAH. This would add more nuanced information about the actual food security outcomes of involvement in industrial crop production in the region. Finally, our study employs standardized metrics of food security. Even though such metrics can offer very powerful information about the impacts of industrial crop production [1], there is a possibility that the obtained results might be affected by the time of the year the survey has been conducted. Future studies should seek to undertake data collection during multiple periods of the year and/or capture "ultimate" measures of food security such as child stunting [1]. 


\section{Conclusions}

This paper assesses the food security outcomes of the involvement in smallholder-based rubber and oil palm production in the Forest Region of Guinea. We have conducted an exploratory rapid assessment that has used multiple standardized metrics of food security to compare the food security status of industrial crop smallholders and subsistence farmers. Our results suggest that subsistence farmers have better food security levels in terms of diet diversity (FCS) but worse levels in terms of perception of hunger (HFIAS). Results for coping behaviors (CSI) are mixed, without any clear pattern or statistically significant differences between groups.

Propensity Score Matching (PSM) and Endogenous Treatment Effect Regression (ETER) analyses indicate that involvement in industrial crop production has different food security outcomes depending on the metric and the crop. Both PSM and ETER converge to reveal that involvement in rubber and oil palm production has a positive effect on food security in terms of perceptions of hunger (HFIAS) and coping behaviors (i.e., CSI). Both models also agree that involvement in rubber production fails to improve dietary diversity (FCS).

Overall, our results suggest that involvement in rubber and oil palm production has different food security outcomes for the different metrics. In particular involvement in industrial crop production largely improves food security outcomes for metrics that entail a subjective awareness of food security but have the opposite effect for measures that entail an objective assessment of food diversity patterns. In this sense involvement in industrial crop production does not enhance consistently food security across all metrics. This can possibly be explained by the strong sense of security that steady and higher income provides across time (food stability), that outweighs the shortcomings of diet diversity (food utilization).

However, caution should be used in interpreting these findings as the tests for some indicators and groups are not statistically significant, possibly due to the small sample sizes used in this study. Future studies should aim to build on this study by (a) increasing sample sizes, (b) including control groups that properly reflect the situation prior to SOGUIPAH interventions, (c) conducting surveys during different times of the year and/or including ultimate measures of food security such as child stunting.

Supplementary Materials: The following are available online at http:/ /www.mdpi.com/2077-0472/9/2/41/s1, Figure S1: Distribution of respondents across food security thresholds for the HHS and rCSI metrics, Figure S2: Propensity score distribution and common support for propensity score estimation for rubber growers and subsistence farmers, Figure S3: Propensity score distribution and common support for propensity score estimation of oil palm growers and subsistence farmers, Table S1: Mean score and distribution across food security thresholds for each study group, Table S2. Mean food security scores for HHS and rCSI and differences between study groups, Table S3. Determinants of participation in industrial crop production, Table S4. Impacts of participation in industrial crop production on HFIAS and HHS, Table S5. Test of balancing for confounders, Table S6. Linear Regression with Endogenous Treatment Effects for participation in rubber production (HHS and rCSI metrics), Table S7. Linear Regression with Endogenous Treatment Effects for participation in oil palm production (HHS and rCSI metrics).

Author Contributions: Conceptualization, B.S.B and A.G.; Methodology, B.S.B, C.R. and A.G.; Formal analysis, B.S.B; Investigation, B.S.B. and M.D.; Data curation, B.S.B. and M.D.; Writing-original draft preparation, B.S.B and A.G.; Writing - review and editing, B.S.B., M.D., C.R. and A.G.; Visualization, B.S.B. and A.G.; Supervision, B.S.B. and A.G.; Project administration, B.S.B. and A.G.; Funding acquisition, A.G.

Funding: This research was funded by Japan Science and Technology Agency (JST) under the Belmont Forum project FICESSA (Food Security Impacts of Industrial Crop Expansion in Sub-Sahara Africa).

Acknowledgments: Authors acknowledge the support of the Japan Science and Technology Agency (JST) for the Belmont Forum project FICESSA (Food Security Impacts of Industrial Crop Expansion in Sub-Sahara Africa). Marcin Jarzebski created Figure 2 and Figure S1, Rodolfo Dam Lam provided comments in a previous version of this paper and Ei Thwe assisted in the editing of this manuscript.

Conflicts of Interest: The authors declare no conflict of interest. 


\section{References}

1. Wiggins, S.; Henley, G.; Keats, S. Competitive or Complementary? Industrial Crops and Food Security in Sub-Saharan Africa; Research Reports and Studies; Overseas Development Institute (ODI): London, UK, 2015.

2. Gasparatos, A.; von Maltitz, G.; Johnson, F.X.; Lee, L.; Mathai, M.; Puppim de Oliveira, J.; Willis, K. Biofuels in Africa: Drivers, impacts and priority policy areas. Renew. Sustain. Energy Rev. 2015, 45, 879-901. [CrossRef]

3. Boafo, Y.A.; Balde, B.S.; Saito, O.; Gasparatos, A.; Lam, R.D.; Ouedraogo, N.; Chamba, E.; Moussa, Z.P. Stakeholder perceptions of the outcomes of reforms on the performance and sustainability of the cotton sector in Ghana and Burkina Faso: A tale of two countries. Cogent Food Agric. 2018, 4, 1477541. [CrossRef]

4. Jones, S.; Gibbon, P. Developing agricultural markets in Sub-Saharan Africa: Organic cocoa in rural Uganda. J. Dev. Stud. 2011, 47, 1595-1618. [CrossRef]

5. Schoneveld, G.C. The geographic and sectoral patterns of large-scale farmland investments in sub-Saharan Africa. Food Policy 2014, 48, 34-50. [CrossRef]

6. Yengoh, G.T.; Armah, F.A. Effects of large-scale acquisition on food insecurity in Sierra Leone. Sustainability 2015, 7, 9505-9539. [CrossRef]

7. Yaro, J.A.; Teye, J.K.; Torvikey, G.D. Agricultural commercialisation models, agrarian dynamics and local development in Ghana. J. Peasant Stud. 2017, 44, 538-554. [CrossRef]

8. Lam, R.D.; Boafo, Y.A.; Degefa, S.; Gasparatos, A.; Saito, O. Assessing the food security outcomes of industrial crop expansion in smallholder settings: Insights from cotton production in Northern Ghana and sugarcane production in Central Ethiopia. Sustain. Sci. 2017, 12, 677-693. [CrossRef]

9. Herrmann, R.; Jumbe, C.; Bruentrup, M.; Osabuohien, E. Competition between biofuel feedstock and food production: Empirical evidence from sugarcane outgrower settings in Malawi. Biomass Bioenergy 2018, 114, 100-111. [CrossRef]

10. Mudombi, S.; von Maltitz, G.P.; Gasparatos, A.; Romeu-Dalmau, C.; Johnson, F.X.; Jumbe, C.; Ochieng, C.; Luhanga, D.; Lopes, P.; Balde, B.S.; et al. Multi-dimensional poverty effects around operational biofuel projects in Malawi, Mozambique and Swaziland. Biomass Bioenergy 2018, 114, 41-54. [CrossRef]

11. White, B.; Borras, S.M.; Hall, R.; Scoones, I.; Wolford, W. The new enclosures: Critical perspectives on corporate land deals. J. Peasant Stud. 2012, 39, 619-647. [CrossRef]

12. Hall, R.; Scoones, I.; Tsikata, D. Plantations, outgrowers and commercial farming in Africa: Agricultural commercialisation and implications for agrarian change. J. Peasant Stud. 2017, 44, 515-537. [CrossRef]

13. World Rainforest Movement (WRM). Oil Palm and Rubber Plantations in Western and Central Africa: An Overview; World Rainforest Movement (WRM): Montevideo, Uruguay, 2008.

14. Romeu-Dalmau, C.; Gasparatos, A.; von Maltitz, G.; Graham, A.; Almagro-Garcia, J.; Wilebore, B.; Willis, K.J. Impacts of land use change due to biofuel crops on climate regulation services: Five case studies in Malawi, Mozambique and Swaziland. Biomass Bioenergy 2018, 114, 30-40. [CrossRef]

15. Ahmed, A.; Kuusaana, E.D.; Gasparatos, A. The role of chiefs in the political economy of large-scale land acquisitions in Ghana: Insights from the jatropha sector. Land Use Policy 2018, 75, 570-582. [CrossRef]

16. Ndjimbi, F. Étude sur l'impact des plantations agro-industrielles de palmiers à huile et d'hévéas sur les populations du Gabon; World Rainforest Movement (WRM): Montevideo, Uruguay, 2013.

17. Achterbosch, T.; Van Berkum, S.; Meijerink, G. Cash Crops and Food Security: Contributions to Income, Livelihood Risk and Agricultural Innovation; LEI Wageningen UR: Wageningen, The Netherlands, 2014.

18. Negash, M.; Swinnen, J.F.M. Biofuels and Food Security: Micro-evidence from Ethiopia. Energy Policy 2013, 61, 963-976. [CrossRef]

19. German, L.; Schoneveld, G.C.; Pacheco, P. The social and environmental impacts of biofuel feedstock cultivation: Evidence from multi-site research in the forest frontier. Ecol. Soc. 2011, 16, 24. [CrossRef]

20. Chinsinga, B. The Green Belt Initiative, Politics and Sugar Production in Malawi. J. South. Afr. Stud. 2017, 43, 501-515. [CrossRef]

21. Matenga, C.R.; Hichaambwa, M. Impacts of land and agricultural commercialisation on local livelihoods in Zambia: Evidence from three models. J. Peasant Stud. 2017, 44, 574-593. [CrossRef]

22. Madelaine, C.; Malezieux, E.; Sibelet, N.; Manlay, R.J. Semi-wild pal groves reveal agricultural change in the forest region of Guinea. Agrofor. Syst. 2008, 73, 189-204. [CrossRef] 
23. Black, R.; Sessay, M. Forced migration, land-use change and political economy in the Forest Region of Guinea. Afr. Aff. 1997, 96, 587-605. [CrossRef]

24. Delarue, J.; Cochet, H. Systemic Impact Evaluation: A Methodology for Complex Agricultural Development Projects. The Case of a Contract Farming Project in Guinea. Eur. J. Dev. Res. 2013, 25, 778-796. [CrossRef]

25. Carrere, R. Oil Palm in Africa: Past, Present and Future Scenarios; World Rainforest Movement (WRM): Montevideo, Uruguay, 2010.

26. Sy, M.A. Étude sur la filière artisanale de l'huile de palme en Guinée; MAE/BCEPA-PASAL: Conakry, Guinea, 2002.

27. Agence Française de Développement (AFD). Developing Smallholder Rubber Production: Lessons from AFD's Experience; Agence Française de Développement (AFD): Paris, France, 2008.

28. Carletto, C.; Zezza, A.; Banerjee, R. Towards better measurement of household food security: Harmonizing Indicators and the role of household surveys. Glob. Food Secur. 2013, 2, 30-40. [CrossRef]

29. Jones, A.D.; Ngure, F.M.; Pelto, G.; Young, S.L. What are we assessing when we measure food security? A compendium and review of current metrics. Adv. Nutr. 2013, 4, 481-505. [CrossRef] [PubMed]

30. Maxwell, D.; Vaitla, B.; Coates, J. How do indicators of household food insecurity measure up? An empirical comparison from Ethiopia. Food Policy 2014, 47, 107-116. [CrossRef]

31. Vaitla, B.; Coates, J.; Glaeser, L.; Hillbruner, C.; Biswal, P.; Maxwell, D. The measurement of household food security: Correlation and latent variable analysis of alternative indicators in a large multi-country dataset. Food Policy 2017, 68, 193-205. [CrossRef]

32. Johnson, F.X.; Nyambane, A.; von Maltitz, G.; Luhanga, D.; Jarzebski, M.; Balde, B.S.; Gasparatos, A. Impacts of Biofuel Crop Production in Southern Africa: Land Use Change, Ecosystem Services, Poverty Alleviation and Food Security; Ecosystem Services for Poverty Alleviation (ESPA): Edinburg, UK, 2018.

33. Thornhill, S.; Vargyas, E.; Fitzgerald, T.; Chisholm, N. Household food security and biofuel feedstock production in rural Mozambique and Tanzania. Food Secur. 2016, 8, 953-971. [CrossRef]

34. Anderman, T.L.; Remans, R.; Wood, S.A.; DeRosa, K.; DeFries, R.S. Synergies and tradeoffs between cash crop production and food security: A case study in rural Ghana. Food Secur. 2014, 6, 541-554. [CrossRef]

35. Hassen, K.; Zinab, B.; Belachew, T. Gender and education as predictors of food insecurity among coffee farming households of the Jimma zone, Southwest of Ethiopia. BMC Nutr. 2016, 2, 75. [CrossRef]

36. Von Maltitz, G.; Gasparatos, A.; Fabricius, C.; Morris, A.; Willis, K.J. Jatropha cultivation in Malawi and Mozambique: Impact on ecosystem services, local human wellbeing and poverty alleviation. Ecol. Soc. 2016, 21, 3. [CrossRef]

37. De Cock, N.; D’Haese, M.; Vink, N.; van Rooyen, C.J.; Staelens, L.; Schonfeldt, H.C.; D’Haese, L. Food security in rural areas of Limpopo province, South Africa. Food Secur. 2013, 5, 269-282. [CrossRef]

38. Baiyegunhi, L.J.S.; Oppong, B.B.; Senyolo, G.M. Mopane worn (Imbrasia belina) and rural household food security in Limpopo province, South Africa. Food Secur. 2016, 8, 153-165. [CrossRef]

39. Kissoly, L.; Fabe, A.; Grote, U. The integration of smallholders in agricultural value chain activities and food security: Evidence from rural Tanzania. Food Secur. 2017, 9, 1219-1235. [CrossRef]

40. World Food Programme (WFP). Comprehensive Food Security and Vulnerability Analysis Guidelines; World Food Programme (WFP): Rome, Italy, 2009.

41. World Food Programme (WFP). Food Consumption Analysis: Calculation and Use of the Food Consumption Score in Food Consumption and Food Security Analysis; World Food Programme (WFP): Rome, Italy, 2007.

42. Dietchler, M.; Ballard, T.; Swindale, A.; Coates, J. Validation of a Measure of Household Hunger for Cross Cultural Use; United States Agency for International Development (USAID): Washington, DC, USA, 2010.

43. Coates, J.; Swindale, A.; Bilinsk, P. Household Food Insecurity Access Scale (HFIAS) for Measurement of Food Access: Indicator Guide; United States Agency for International Development (USAID): Washington, DC, USA, 2007.

44. Maxwell, D.; Caldwell, R. The Coping Strategies Index: Field Methods Manual, 3rd ed.; United States Agency for International Development (USAID): Washington, DC, USA, 2008.

45. Maxwell, D.; Watkins, B.; Wheeler, R.; Collins, G. The Coping Strategies Index: Field Methods Manual, 1st ed.; United States Agency for International Development (USAID): Washington, DC, USA, 2003.

46. Swindale, A.; Bilinsky, P. Months of Adequate Household Food Provisioning (MAHFP) for Measurement of Household Food Access; United States Agency for International Development (USAID): Washington, DC, USA, 2007.

47. Rosenbaum, P.R.; Rubin, D.B. The central role of the propensity score in observational studies for causal effects. Biometrika 1983, 70, 41-55. [CrossRef] 
48. Chiputwa, B.; Spielman, D.J.; Qaim, M. Food Standards, Certification and Poverty among Coffee Farmers in Uganda. World Dev. 2015, 66, 400-412. [CrossRef]

49. Mwangi, J.K.; Crewett, W. The impact of irrigation on small-scale African indigenous vegetable Growers' market access in peri-urban Kenya. Agric. Water Manag. 2019, 212, 295-305. [CrossRef]

50. Gitonga, Z.M.; De Groote, H.; Kassie, M.; Tefera, T. Impact of metal silos on households' maize storage, storage losses and food security: An application of a propensity score matching. Food Policy 2013, 43, 44-55. [CrossRef]

51. Mitiku, F.; de Mey, Y.; Nyssen, J.; Maertens, M. Do Private Sustainability Standards Contribute to Income Growth and Poverty Alleviation? A Comparison of Different Coffee Certification Schemes in Ethiopia. Sustainability 2017, 9, 246. [CrossRef]

52. Awotide, B.A.; Alene, A.D.; Abdoulaye, T.; Manyong, V.M. Impact of agricultural technology adoption on asset ownership: The case of improved cassava varieties in Nigeria. Food Secur. 2015, 7, 1239-1258. [CrossRef]

53. Caliendo, M.; Kopeinig, S. Some practical guidance for the implementation of propensity score matching. J. Econ. Surv. 2008, 22, 31-72. [CrossRef]

54. Rosenbaum, P.R.; Rubin, D.B. Constructing a control group using multivariate matched sampling methods that incorporate the propensity score. Am. Stat. 1985, 39, 33-38.

55. Mathiassen, A.; Hollema, S. What is the effect of physical activity level on food consumption, energy deficiency and dietary diversity? Food Nutr. Bull. 2014, 35, 351-360. [CrossRef]

56. Feleke, S.; Kilmer, R.L.; Gladwin, C. Determinants of food security in Southern Ethiopia. Agric. Econ. 2005, 33, 351-363. [CrossRef]

57. Kaloi, E.; Tayebwa, B.; Bashaasha, B. Food security status of households in Mwingi district, Kenya. Afr. Crop Sci. Conf. Proc. 2005, 7, 867-873.

58. Turyahabwe, N.; Kakuru, W.; Tweheyo, M.; Tumusiime, D.M. Contribution of wetland resources to household food security in Uganda. Agric. Food Secur. 2013, 2, 5. [CrossRef]

59. Silvestri, S.; Sabine, D.; Patti, K.; Wiebke, F.; Maren, R.; Ianetta, M.; Carlos, Q.F.; Mario, H.; Anthony, N.; Nicolas, N.; et al. Households and food security: Lessons from food secure households in East Africa. Agric. Food Secur. 2015, 4, 23. [CrossRef]

60. Famine Early Warning Systems Network (FEWS NET). Guinea. Food Security Outlook: October 2016 through May 2017; Famine Early Warning Systems Network (FEWS NET): Washington, DC, USA, 2017.

61. Famine Early Warning Systems Network (FEWS NET). Guinea Food Security Outlook: February through September 2017; Famine Early Warning Systems Network (FEWS NET): Washington, DC, USA, 2017.

62. Famine Early Warning Systems Network (FEWS NET). Liberia Food Security Outlook: February to September 2016; Famine Early Warning Systems Network (FEWS NET): Washington, DC, USA, 2017.

63. Manda, J.; Gardebroek, C.; Khonje, M.G.; Alene, A.D.; Mutenje, M.; Kassie, M. Determinants of child nutritional status in the eastern province of Zambia: The role of improved maize varieties. Food Secur. 2016, 8, 239-253. [CrossRef]

(C) 2019 by the authors. Licensee MDPI, Basel, Switzerland. This article is an open access article distributed under the terms and conditions of the Creative Commons Attribution (CC BY) license (http://creativecommons.org/licenses/by/4.0/). 